\title{
Bank Lending During Recessions
}

Maximiliano Dvorkin, Economist

Hannah Shell, Research Associate oan growth at commercial banks decreased substantially and remained negative for almost four years after the 2007-08 financial crisis. In contrast, loan growth patterns during the 1990-91 and 2001 recessions were more moderate. Figure 1 illustrates the evolution of the growth rate of loans and leases at commercial banks during and after the three most recent recessions. ${ }^{1}$ In each case, the starting period is the quarter including the official recession start date as determined by the National Bureau of Economic Research. Lending growth slowed to zero during the 1990-91 and 2001 recessions but recovered after a few quarters. In contrast, during the Great Recession (2007-09), loan growth became strongly negative and remained so for almost four years.

The varying evolutions of loan growth could be due to differences in demand, supply, or a combination of both. The Senior Loan Officer Opinion Survey on Bank Lending Practices administered by the Board of Governors of the Federal Reserve System might shed some light on these differences. This quarterly survey questions loan officers at about 80 U.S. commercial banks about recent changes in lending standards and loan demand. The responses are compiled into a special type of index-a diffusion indexavailable in FRED ${ }^{\circledR}$ (Federal Reserve Economic Data). ${ }^{2}$

Figure 2

\section{A. Commercial and Industrial Lending Standards}

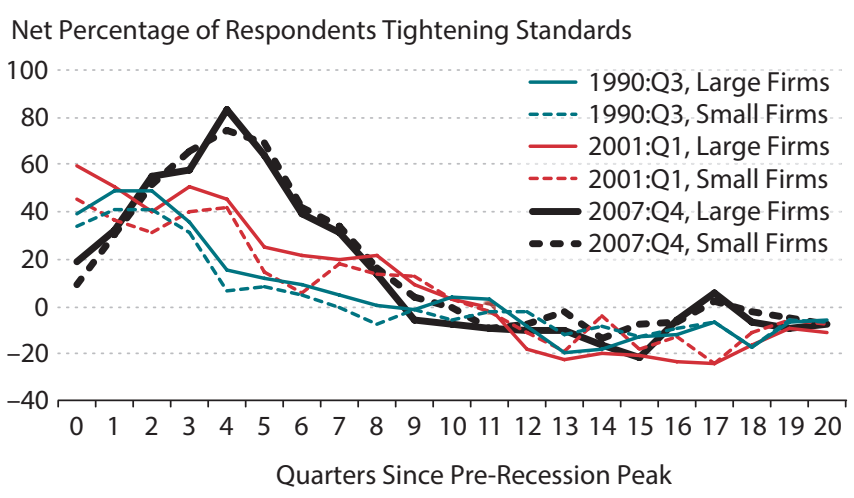

Figure 1

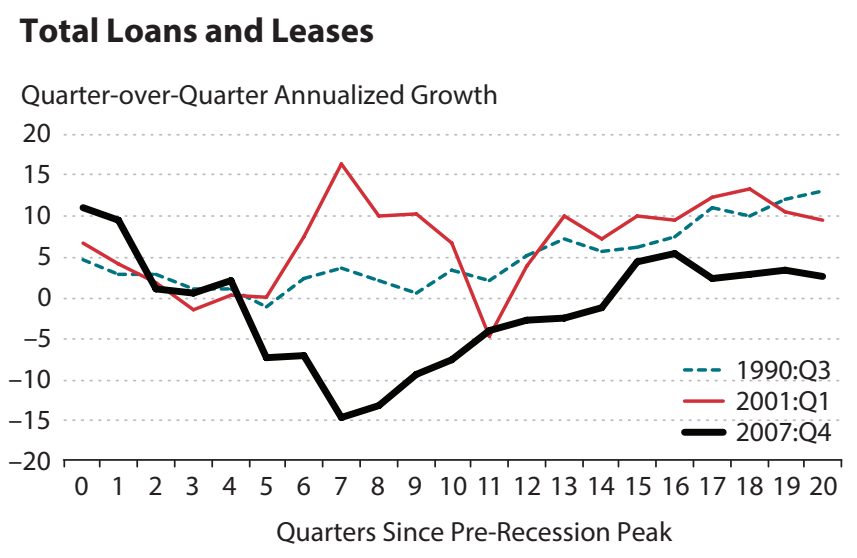

SOURCE: FRED ${ }^{\circledast}$ (Federal Reserve Economic Data), Federal Reserve Bank of St. Louis, and Board of Governors of the Federal Reserve System.

Reports of tightening lending standards would indicate supply factors were responsible for the slowdown in loan growth, while reports of decreased loan demand would presumably indicate demand factors.

Figures $2 \mathrm{~A}$ and $2 \mathrm{~B}$ show the net percentage of loan officers reporting tighter standards on commercial and industrial loans and revolving consumer loans (i.e., credit

\section{B. Consumer Lending Standards: Credit Cards}

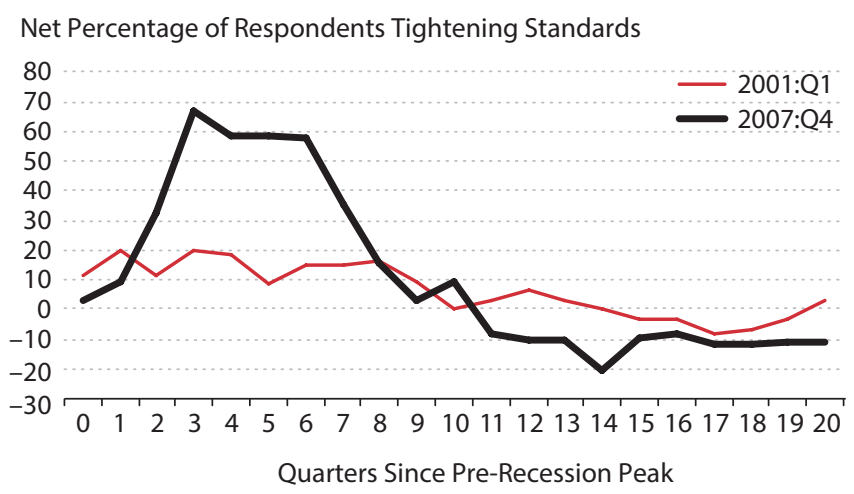

NOTE: Small firms: annual sales $<\$ 50$ million. Large firms (includes medium-sized firms): annual sales $\geq \$ 50$ million.

SOURCE: FRED ${ }^{\circledast}$ (Federal Reserve Economic Data), Federal Reserve Bank of St. Louis, and Board of Governors of the Federal Reserve System. 
Figure 3

\section{A. Commercial and Industrial Loan Demand}

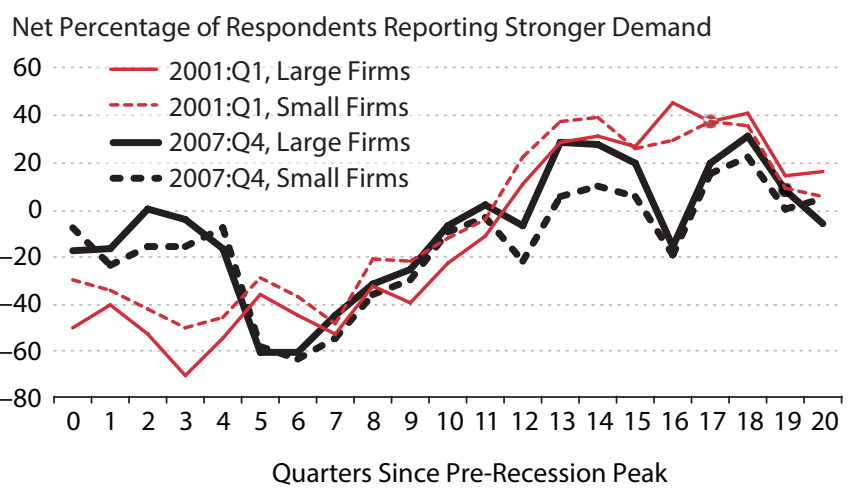

\section{B. Consumer Loan Demand}

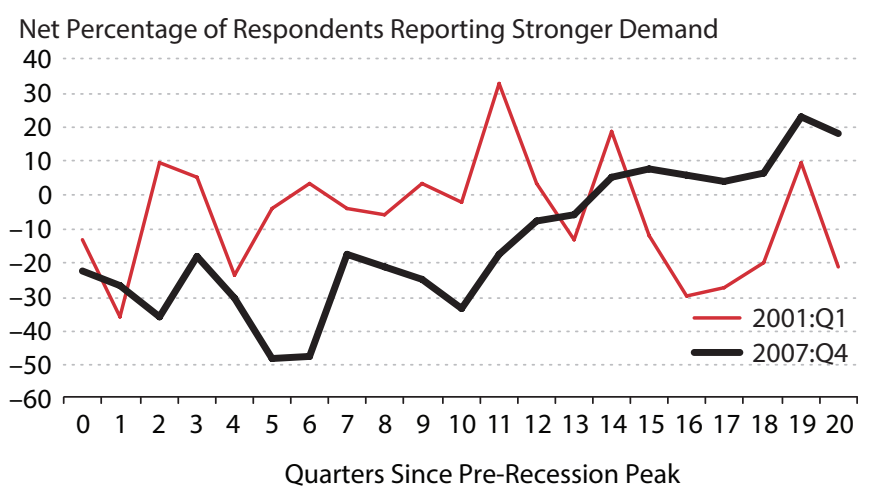

NOTE: Small firms: annual sales $<\$ 50$ million. Large firms (includes medium-sized firms): annual sales $\geq \$ 50$ million.

SOURCE: Panel A: FRED ${ }^{\circledast}$ (Federal Reserve Economic Data), Federal Reserve Bank of St. Louis, and Board of Governors of the Federal Reserve System.

Panel B: Board of Governors of the Federal Reserve System and Haver.

\section{Tightening of lending standards can account for part of the negative loan growth during the 2007-09 recession.}

cards), respectively. ${ }^{3}$ The starting dates match those in Figure $1 .{ }^{4}$ As the figures show, loan officers reported a tendency to tighten lending for both business and consumer loans during all three recessions; more reported doing so during the most recent downturn. Tightening of standards reduces the loan supply and can account for part of the negative loan growth during the 2007-09 recession.

Figures $3 \mathrm{~A}$ and $3 \mathrm{~B}$ show the net percentage of officers who reported stronger demand for business loans and consumer loans, respectively, during the two most recent recessions-2001 and 2007-09. On the one hand, loan officers perceived weaker demand for business loans in both recessions, with the falloff in demand appearing roughly similar (see Figure 3A). On the other hand, loan officers perceived consumer demand in the 2007-09 recession as much weaker and that weaker demand to be more protracted than in the 2001 recession (see Figure 3B). Comparison of these survey results across recessions seems to indicate that both supply and demand factors contributed to the sharp drop in bank lending during the Great Recession.

\section{NOTES}

1 In the context of bank financing, a lease is an agreement that transfers the right to use land, buildings, or equipment for a specified period of time. This financing device is essentially an extension of credit evidenced by an obligation between a lessee and a lessor.

2 We use the following series in FRED (https://research.stlouisfed.org/fred2/): LLBACBQ158SBOG (total loans and leases); DRTSCILM (lending standards for commercial and industrial loans to large firms); DRTSCIS (lending standards for commercial and industrial loans to small firms); DRTSCLCC (lending standards for consumer credit card loans); DRSDCILM (loan demand from large and medium-sized firms); and DRSDCIS (loan demand from small firms). (Small firms are those with annual sales less than $\$ 50$ million. Large and mediumsized firms are those with annual sales of $\$ 50$ million or more.) These series are reported as diffusion indexes. A diffusion index is calculated by taking the number of respondents reporting an increasing change (e.g., tightening standards or stronger demand) minus the number of respondents reporting a decreasing change (e.g., looser standards or lower demand) divided by the total respondents (including those reporting no change).

3 Data on lending standards for other consumer loan categories are not available prior to 2011.

${ }^{4}$ Data on lending standards for consumer loans are not available for the 1990-91 recession. 